\title{
ІНФОРМАЦІЙНІ ТЕХНОЛОГІЇ В ЗАБЕЗПЕЧЕННІ ЕФЕКТИВНОСТІ ДОПОМІЖНОГО ЛАЗЕРНОГО ХЕТЧИНГУ
}

С. В. Денисенко

\author{
Клініка проблем планування сім'ї МОЗ України
}

У статті проаналізовано проблеми підвищення ефективності використання допоміжного лазерного хетчингу для забезпечення якості роботи IVF лабораторії.

Ключові слова: інформаційні технології, допоміжний хетчинг, лазер, ДРТ.

\section{ИНФОРМАЦИОННЫЕ ТЕХНОЛОГИИ В ОБЕСПЕЧЕНИИ ЭФФЕКТИВНОСТИ ВСПОМОГАТЕЛЬНОГО ЛАЗЕРНОГО ХЕТЧИНГА}

С. В. Денисенко

\author{
Клиника проблем планирования семьи МЗ Украины
}

В статье проанализированы проблемы повышения эффективности использования вспомогательного лазерного хэтчинга для обеспечения качества работы IVF лаборатории.

Ключевые слова: информационные технологии, вспомогательный хэтчинг, лазер, ВРТ.

\section{INFORMATION TECHNOLOGIES IN PROVIDING OF EFFICIENCY OF ASSISTED LASER HATCHING}

S. V. Denysenko

\author{
The Clinic of Human Reproduction Problems, Ministry of Public Health of Ukraine
}

\begin{abstract}
In the article the problems of effectiveness increasing of using of assisted laser hatching to enhance the quality of the IVF laboratory were analyzed.
\end{abstract}

Key words: informational technology, assisted hatching, laser, ART.

Вступ. Сучасні допоміжні мікроманіпуляції з ембріонами виконують із використанням лазерної системи. Перші роботи з застосування лазера в мікроманіпуляціях із гаметами та ембріонами проведено в 1988 р. Спочатку дослідження впливу лазера на ділянку пелюциду проводили на ооцитах мишей і хом'яків $[1,2,3,4]$. У 1990 р. завдяки розробкам Д. Коена в клінічну практику впроваджено технологію насічок (штрихування), яка виконується за допомогою лазерної системи (лазерний допоміжний хетчинг) [2].

Лазерний хетчинг вперше використано у 1991 p. [11]. Відомо два варіанти хетчингу за допомогою лазерної системи: 1) безконтактний метод - оболонку ембріона пробивають наскрізь під кутом; 2) контактний метод - припускає використання лазера 3 дуже коротким променем, який пробиває оболонку і закінчується безпосередньо біля ембріона. Використання лазерної установки значно полегши(c) С. В. Денисенко ло проведення цих маніпуляцій і сьогодні є рутинною процедурою.

У перші роки застосування допоміжних репродуктивних технологій (ДРТ) високий відсоток ембріонів 3 ущільненням зони пелюциду пояснювався відсутністю в культуральних середовищах необхідних для хетчингу лізинів [5]. Для поліпшення показника імплантації ембріонів з ущільненою зоною пелюциду Д. Коен і колеги розробили маніпуляцію допоміжного хетчингу, який є ембріологічною мікроманіпуляцією, в ході якої виконують розсічення або надсічення зони пелюциду ембріона в певній фазі його розвитку для полегшення звільнення від оболонки та підвищення імовірності імплантації [2 ].

Разом 3 тим застосування допоміжного хетчингу не завжди буває результативним. За даними літератури, частота вагітності та імплантації ембріонів складає відповідно 51,8 і 26,5\% [6]. 
Мета роботи - визначення показників, які зумовлюють ефективність лазерного хетчингу й обгрунтування іiі підвищення шляхом застосування інформаційних технологій прогнозування наслідків використання хетчингу.

Основна частина. Ефективність проведення допоміжного лазерного хетчингу вивчали в Клініці проблем планування сім 'ї (КППС) в рамках пілотного дослідження для 25 жінок. Застосовували метод лазерного хетчингу як найефективнішого для роботи з ембріоном.

Для уникнення можливого впливу лазера на ембріон і для згладжування оболонки замість їі пробиття застосовували безконтактний метод.

Для допоміжного хетчингу використовували лазерну систему OCTAX Laser Shot, яка включає компоненти: модуль ОСТАХ Laser Shot; комп'ютер із програмним забезпеченням OCTAX EyeWare; OCTSX Laser Lens; цифрову USB камеру ОСТАХ Еуе; адаптер до мікроскопа.

Процедуру проводили за допомогою 1,48 мм-діодного лазера, який забезпечує швидке й ефективне відкривання зони пелюциду (рис. 1).

Промінь діодного лазера контролювали через оптичну систему мікроскопа та фокусували на цілі. Для даної довжини хвилі немає необхідності у використанні спеціальної оптичної системи і чашок для культивування, використовують чашки для стандартного культивування клітин. У ході процедури відбувався безконтактний вплив лазерного променя.

За допомогою програмного забезпечення ОСТАХ EyeWare візуалізували й архівували зображення; контролювали роботу мікроскопа, отримували мікроскопічне зображення. Програмне забезпечення системи ОСТАX Laser Shot дозволяє здійснювати складні, високотехнологічні мікроманшуляції з клітиною в програмах ДРТ.

Для обчислення прогностичної значущості клінічних ознак у прогнозуванні ефективності лазерного хетчингу застосували критерій Стьюдента у модифікації М. М. Амосова зі співавторами (1975). Суть його полягає у порівнянні частоти несприятливого результату в усіх хворих за наявності досліджуваної ознаки $\left(\mathrm{P}_{1}\right)$ із середньою частотою несприятливого результату в усіх хворих, обстежених за цим показником $\left(\mathrm{P}_{0}\right)$. Відповідне математичне значення має вигляд:

$$
\mathrm{t}=\frac{P-P_{0}}{\sqrt{m_{1}^{2}+m_{0}^{2}}},
$$

де $\mathrm{t}$ - інформативність ознаки, бали; $ш_{1}$ i $\mathrm{T}_{0}$ - ceредні похибки величин $\mathrm{P}_{1}$ i $\mathrm{P}$
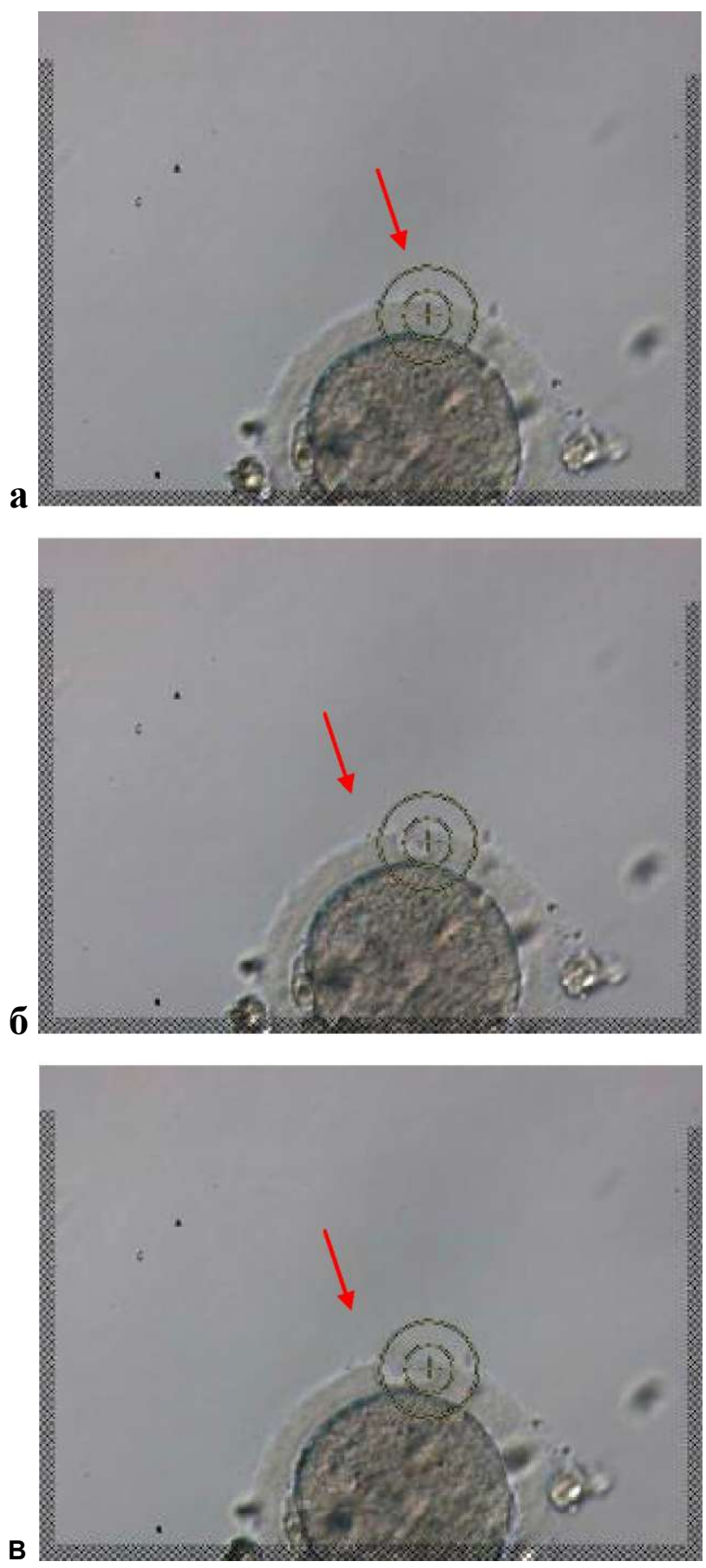

Puc. 1. Послідовність проведення лазерного хетчингу: фокусування лазера на ділянці пелюциду (a); зона пелюциду після пострілу лазера (б); зона пелюциду після другого пострілу лазера (для збільшення отвору) (в).

Припускали статистичну незалежність ознак (симптомів і синдромів), які застосовували для прогнозування ефективності хетчингу.

Вивчали прогностичну значущість клінічних показників для лазерного хетчингу, згрупованих за факторами (табл. 1). 
МЕДИЧНА ІНФОРМАТИКА

TA ІНЖЕНЕРІЯ

Таблиця 1. Показання до застосування допоміжного хетчингу

\begin{tabular}{|l|l|}
\hline \multicolumn{1}{|c|}{ Фактори } & \multicolumn{1}{|c|}{ Групи } \\
\hline Віковий показник & Жінки > 37 років \\
\hline Гормональний статус & Підвищений рівень ФСГ в організмі жінки \\
\hline Якість ембріонів & $\begin{array}{l}\text { Ущільнення зони пелюциду, низька швидкість дроблення, високий рівень } \\
\text { фрагментації клітин, збільшення перивітелінового простору, атипова форма } \\
\text { ембріона }\end{array}$ \\
\hline Програми ДРТ & $\begin{array}{l}\text { Одна безрезультатна програма ДРТ в КППС* (до впровадження процедури } \\
\text { хетчингу); багаторазові безрезультатні спроби (в середньому 4-5) в інших } \\
\text { медичних закладах }\end{array}$ \\
\hline
\end{tabular}

На першому етапі дослідження визначили інформативність (прогностичну значущість) клінічних ознак для обгрунтування вибору хетчингу. Значущість ознак за критерієм М. М. Амосова зі співавт. дорівнювала: вік пацієнток понад 37 років (інформативність 7,9); попередні невдалі спроби прикріплення ембріона $(\mathrm{I}=6,8)$, ембріони 3 поганими показниками якості $(\mathrm{I}=6,2)$; високий рівень фолікулостимулювального гормону росту $(\mathrm{I}=5,9)$; куріння $(\mathrm{I}=5,5)$.

При сумі балів ризику більше 15 дещо змінювали методику лазерного опромінювання. В результаті проведення лазерного хетчингу для вказаних ембріонів виявлено суттєво підвищений рівень імплантації на перенесений ембріон. Після здійснення процедури в групі з 25 жінок вагітність настала у 17 (68\%).

Зауважимо, що отримані дані досить високі. Порівняння отриманих нами результатів із вказаними вище засвідчило суттєве підвищення результативності програми ДРТ при застосуванні допоміжного лазерного хетчингу.

Одним із факторів успішного проведення програм ДРТ є здатність ембріона імплантуватися в стінці матки, що, в свою чергу, залежить від якості самого ембріона та стану зони пелюциду. Як відомо, ооцити та преімплантаційні ембріони оточені захисною двошаровою оболонкою - зоною пелюциду, товщина якої становить 13-15 мкм. Зона пелюциду виконує захисну роль після запліднення природним шляхом, не дозволяючи іншим сперматозоїдам проникнути під неї, а також полегшуючи й оберігаючи транспорт ембріона під час його проходження по маткових трубах. При потраплянні ембріона в порожнину матки ділянка пелюциду стоншується, ембріон звільняється від оболонки, відбувається природний хетчинг - так зване сповзання оболонки і «прокльовування» ембріона. В основі процесу природного хетчингу лежить вироблення літичних ферментів клітинами трофодерми - безпосередньо перед хетчингом трофодерма ембріона експресує трипсин. Успішний результат процесу хетчингу залежить від товщини й еластичності оболонки. У жінок старшої вікової групи товщина і щільність оболонки змінюється, що зумовлено молекулярними змінами в самій оболонці [7, 8] (рис. 2).
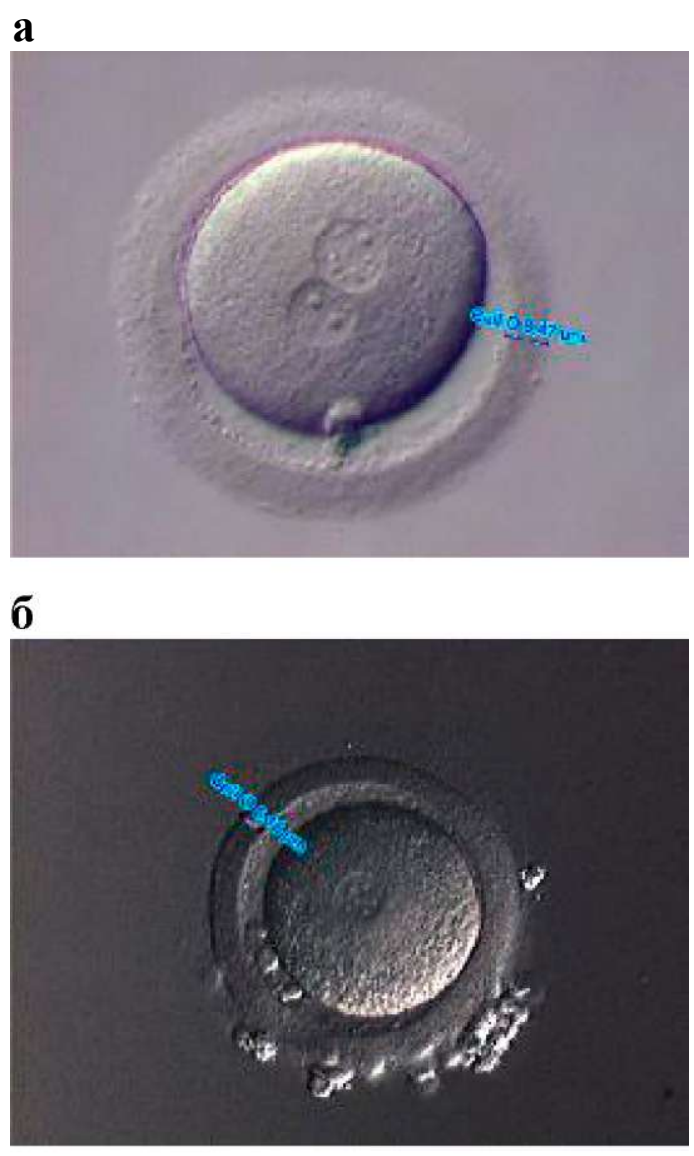

B

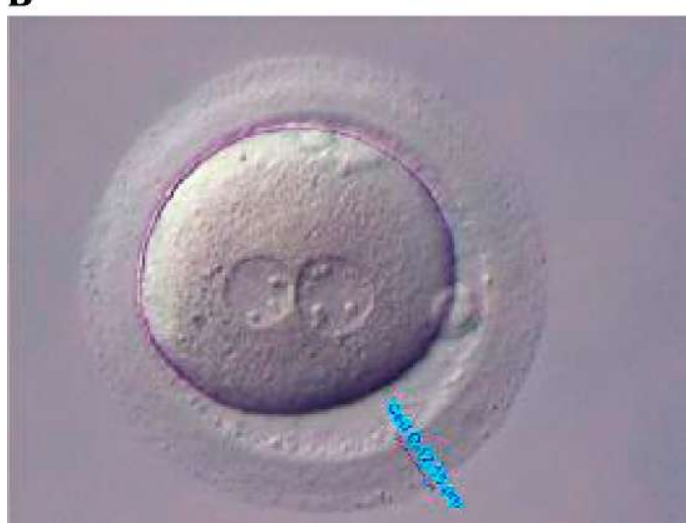

Puc. 2. Ембріони з різною товщиною зони пелюциду: нормальна зона пелюциду (а); тонка зона пелюциду (б); товста зона пелюциду (в). 
На відміну від природного запліднення, в стимульованих циклах у програмах ДРТ спостерігають асинхронність між розвитком ембріона та «вікном» імплантації в ендометрії, при цьому «вікно» імплантації зсувається, відповідно час для імплантації ембріонів обмежений, що може зумовлювати низьку частоту настання вагітності. Постає питання про поліпшення умов імплантації ембріонів після їх перенесення в порожнину матки [9].

\section{Лiтература}

1. Wassarman P. M. Zona pellucida glycoproteins / P. M. Wassarman // Ann. Rev. Biochem. - 1988. - Vol. 57. - P. 415-442.

2. Impairment of the hatching process following IVF in the human and improvement of implantation by assisted hatching using micromanipulation / J. Cohen, C. Elsner, H. Kort [et al.] // Hum. Reprod. - 1990. - Vol. 5. - P. 7-13.

3. Hughes D. C. Identification of the true human orthologue of the mouse $Z p$ gene: evidence for greater complexity in the mammalian zona pellucida? / D. C. Hughes, C. L. R. Barratt// Biochem. Biophys. Acta. - 1999. - Vol. 1447. - P. 303-306.

4. Ebner T. Possible applications of a non_contact 1.48 мш wavelength diode laser in assisted reproduction technologies / T. Ebner, M. Moser, G. Tews // Hum. Reprod. Update. - 2005. - Vol. 11. - P. 425-435.

5. Cohen J. Advances in methodologies aimed at enhancing the viability of in vitro cultured human embryos / J. Cohen, K. E. Wiemer// Baillieres Clin. Obstet. Gynaecol. - 1992. - Vol. 6. - P. 297-311.

6. Implantation enhancement by selective assisted hatching
Висновки. 1. Допоміжний лазерний хетчинг забезпечує підвищення ефективності програми ДРТ. Процедура безпечна й ефективна при дотриманні відповідних правил виконання та високої кваліфікації ембріолога.

2. 1,48 мм-діодний лазер у процедурі допоміжного хетчингу - альтернатива традиційним методикам (механічній і хімічній).

using zona drilling of human embryos with poor prognosis / J. Cohen, M. Alikani, J. Trowbridge, Z. Rosenwaks // Hum. Reprod. - 1992. - Vol. 7. - P. 685-691.

7. Laser_assisted hatching of embryos in women of advanced age after in vitro fertilization: a preliminary report / S. G. Horng, C. L. Chang, H. M. Wu [et al.] // Chang Gung Med. J. - 2002. Vol. 25. - P. 531-537.

8. Zona thinning with a noncontact diode laser in ICSI embryos from women of advanced age / C. G. Petersen, A. L. Mauri, R. L. R. Baruffi [et al.] // J. Assist. Reprod. Genet. - 2002. - Vol. 19. - P. 512-516.

9. Assisted hatching on assisted conception (IVF and ICSI) / M. M. W. Seif, E. C. O. Edi-Osagie, C. Farquhar [et al.] // Cochrane Database Syst. Rev. - 2006. - Vol. 1. - CD001894.

10. Clinical application of laser_assisted ICSI: a pilot study / L. Rienzi, F. Ubaldi, F. Martinez [et al.] // Eur. J. Obstet. Gynecol. Reprod. Biol. - 2004. - Vol. 115, Suppl. 1. - P. 77-79.

11. Micromanipulation of gametes using laser microbeams / Y Tadir, W. H. Wright, O. Vafa [et al.] // Hum. Reprod. - 1991. Vol.. 6. - P. 1011-1016. 